dr inz. Jan Matej

Politechnika Warszawska

\title{
Wpływ asymetrii struktury dwuosiowych wózków na bezpieczeństwo ruchu wagonu pasażerskiego
}

\begin{abstract}
$W$ artykule przedstawiono wyniki badań symulacyjnych dla modelu wagonu pasażerskiego, którego nadwozie opiera się na dwóch wózkach asymetrycznych z tzw. wahaczowym prowadzeniem zestawów kół. Do zbudowania modelu wagonu pasażerskiego z wózkami asymetrycznymi oraz wykonania obliczeń wybrano program Adams/Rail. Zakres badań symulacyjnych, dotyczacych dynamicznych właściwości modelu wagonu pasażerskiego z wózkami asymetrycznymi, zawėżno do oceny zagrożenia wykolejeniem na torze zakrzywionym. Najistotniejsze wyniki przedstawiono $w$ formie graficznej.
\end{abstract}

\section{WSTĘP}

Wpływ asymetrii struktury dwuosiowego wózka kolejowego na stateczność wagonu towarowego w ruchu po torze prostym analizowano w [6]. Wśród wyróżnionych tam wariantów szczególną uwagę zwrócono na układ, w którym dwa sąsiednie zestawy kół w obrębie wózka posiadają różne nominalne promienie toczenia $r_{1} \neq r_{2}$, co prowadzi do asymetrii konstrukcji względem pionowej, poprzecznej płaszczyzny przechodzącej przez środek ramy. Wyniki badań na liniowych modelach matematycznych pozwolity ustalić właściwe relacje pomiędzy wielkościami promieni nominalnych oraz dobrać parametry konstrukcyjne, zapewniające wysoką prędkość krytyczną wagonu w ruchu po torze prostym.

\section{OBIEKT BADAŃ SYMULACYJNYCH}

W artykule przedstawiono wyniki badań symulacyjnych dla modelu wagonu pasażerskiego, którego nadwozie opiera się na dwóch wózkach asymetrycznych $\mathrm{z}$ tzw. wahaczowym prowadzeniem zestawów kół - rys.1. Tego typu prowadzenie zestawów kół $\mathrm{w}$ ramie stosowane jest $\mathrm{w}$ wielu współczesnych konstrukcjach [2,4 i 7], np. w wózkach FIAT 0270, Y32E, 11AN, BKW200, 25AN3 - rys.2, ale nie są to wózki z asymetrią opisaną w punkcie 1 .

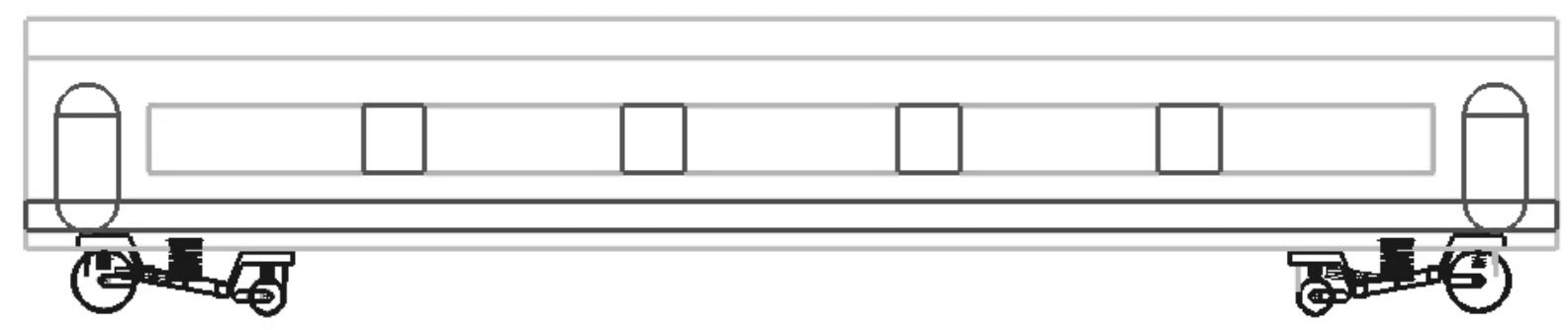

Rys.1 Model wagonu pasażerskiego z wózkami asymetrycznymi

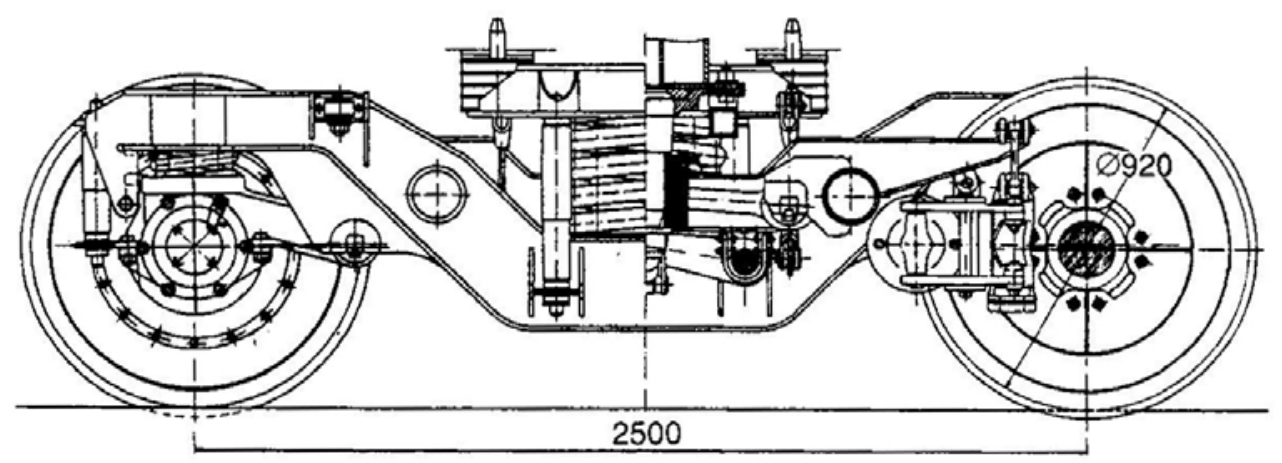

Rys.2 Wózek typu 25AN3 do wagonów pasażerskich 
Podejmując badania bezpieczeństwa ruchu wagonu pasażerskiego $\mathrm{z}$ wózkami o różnych średnicach kół (rys.3 i 4), zachowano wybrane elementy konstrukcyjne wózków symetrycznych. Wahacze $\mathbf{3}$, będące integralną częścią obudowy łożysk osiowych (rys.3), połączone są z ramą wózka 4 poprzez przeguby metalowo-gumowe. Pierwszy stopień zawieszenia realizowany jest przez 4 komplety sprężyn śrubowych 5, umieszczonych pomiędzy korpusami łożysk osiowych i ramą wózka. Drugi stopień zawieszenia to dwie, wielkogabarytowe sprężyny $\mathbf{6}$, znajdujące się pomiędzy ramą wózka i nadwoziem. Pomiędzy ramą wózka i nadwoziem znajdują się również thumiki wężykowania 7 , thumiki poprzeczne $\mathbf{8}$ oraz ograniczniki 9 poprzecznego przesuwu nadwozia względem wózka (rys.4). Drgania w płaszczyźnie pionowej thumione są przy pomocy hydraulicznych thumików drgań $\mathbf{1 0}$ pierwszego stopnia oraz $\mathbf{1 1}$ drugiego stopnia zawieszenia.

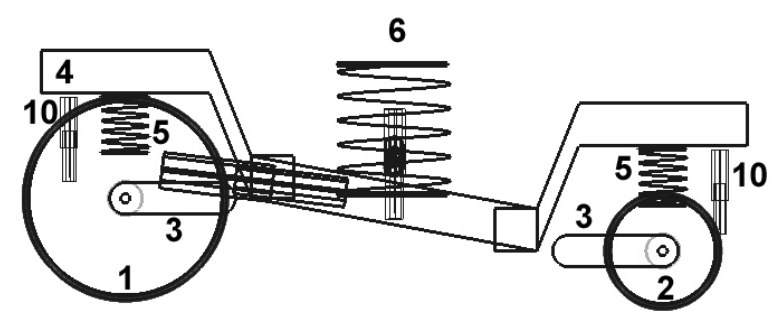

Rys.3 Elementy zawieszenia wózka asymetrycznego

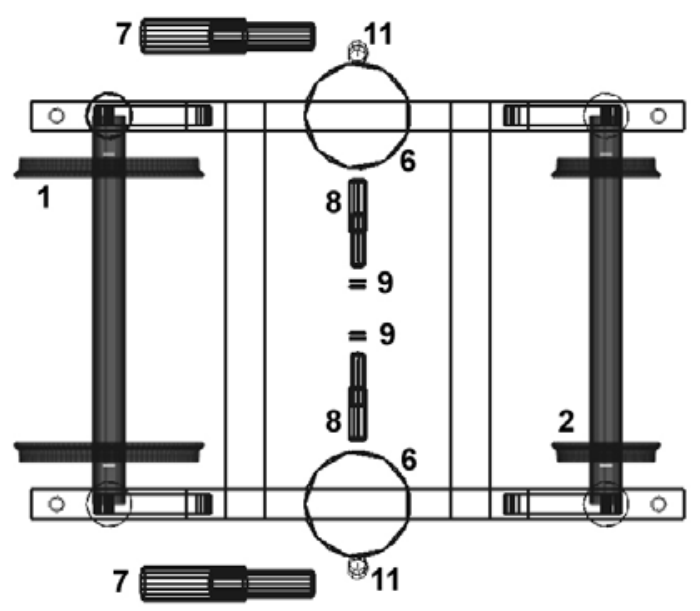

Rys.4 Elementy tłumienia drgań wózka asymetrycznego

\section{METODOLOGIA BADAŃ SYMULACYJ- NYCH}

$\mathrm{Na}$ przestrzeni ostatnich kilkunastu lat badania symulacyjne stały się ważnym elementem projektowania i badań dynamiki pojazdów szynowych. Nowoczesne pakiety oprogramowania umożliwiają realizację standardowych oraz nietypowych scenariuszy symulacyjnych.
Podstawowa teoria związana $\mathrm{z}$ dynamiką układów o wielu stopniach swobody dotyczy skończonej liczby ciał doskonale sztywnych, połączonych ze sobą idealnymi, pozbawionymi masy parami kinematycznymi i elementami siłowymi, występującymi w postaci więzów kinematycznych, sił czynnych oraz momentów działających na ciała. Taki układ mechaniczny nazywany jest układem MBS lub układem wieloczłonowym, a programy umożliwiające zbudowanie modelu danego układu i wykonanie symulacji - programami MBS. Cechą charakterystyczną tych programów jest to, że po zbudowaniu modelu (w oparciu o dostępne biblioteki elementów tworzących strukturę układu), równania ruchu generowane są automatycznie, a czas potrzebny na uzyskanie wyników obliczeń jest krótki. W ogólnym przypadku są to nieliniowe równania różniczkowe. Przykładem specjalistycznych programów MBS, wykorzystywanych do badania dynamiki pojazdów szynowych, są np. MEDYNA, VAMPIRE, ADAMS/RAIL. W programach MBS nie ma wstępnych ograniczeń na liczbę stopni swobody dla połączonych ze sobą ciał sztywnych. Więzy kinematyczne są rezultatem występowania "idealnych" połączeń, pozwalających na wprowadzenie odpowiednich ograniczeń ruchu i sformułowanie właściwego opisu matematycznego [8,9 i 10].

Do zbudowania modelu wagonu pasażerskiego z wózkami asymetrycznymi oraz wykonania obliczeń wybrano program ADAMS/RAIL, w którym na kompletny model badanego układu składają się modele: pojazdu, toru oraz kontaktu koła z szyną.

Model pojazdu zawiera wszystkie informacje dotyczące konstrukcji, tzn.: elementów sprężystych i thumiących zawieszenia, ograniczników itp.

W modelu toru zawarty jest analityczny opis położenia toru (pozioma i pionowa krzywizna toru, przechyłka, rozstaw toru) łącznie z nierównościami geometrycznymi (zmierzonymi lub wygenerowanymi analitycznie) oraz opisem profili kół i szyn (stałych lub zmiennych wzdłuż szyny).

Model kontaktu opisuje oddziaływanie koła z szyna. Do obliczeń stateczności zastosowano model QLT opisujący kontakt quasi-liniowy kół i szyn, natomiast $\mathrm{w}$ analizie dynamicznej wprowadzono model $\mathrm{TAB}-$ wykorzystujący specjalnie przygotowaną tablicę parametrów kontaktowych, które umożliwiają wyznaczenie nieliniowej geometrii kontaktu w czasie symulacji.

Charakterystyczną cechą pojazdów szynowych jest to, że przemieszczają się one wzdhuż toru kolejowego, a kontakt pomiędzy stalowym kołem i stalową szyną oznacza przenoszenie sił stycznych przez mały obszar styku. $Z$ tego powodu model kontaktu stanowi bardzo ważny element programów MBS, przeznaczonych do badania dynamiki pojazdów szynowych. Szczególne znaczenie posiada matematyczny opis układu koło-szyna. Program Adams/Rail traktuje ciała 
tworzące kontakt koło-szyna jako zamknięty łańcuch kinematyczny. Równania ruchu pojazdu przedstawiane są we współrzędnych położenia $\mathrm{p}(\mathrm{t})$ i współrzędnych prędkości $\mathrm{v}(\mathrm{t})$, jako równania Lagrange'a pierwszego rodzaju:

$$
\begin{gathered}
\dot{\mathbf{p}}=\mathbf{v} \\
\mathbf{M}(\mathbf{p}, t) \dot{\mathbf{v}}=\mathbf{f}(\mathbf{p}, \mathbf{v}, \lambda, t)-\mathbf{G}^{\mathbf{T}}(\mathbf{p}, t) \lambda \\
\mathbf{0}=\mathbf{g}(\mathbf{p}, t)
\end{gathered}
$$

które tworzą układ równań różniczkowo-algebraicznych [9].

Algebraiczne równania więzów (3) opisują warunki kontaktu pomiędzy kołem i szyną. Mnożniki Lagrange'a $\lambda(t)$ odpowiadają siłom działającym w punktach styku, prostopadłym do profili koła i szyny:

$$
\mathbf{G}(\mathbf{p}):=\partial \mathbf{g}(\mathbf{p}) / \partial \mathbf{p}
$$

Wektor sił czynnych $\mathbf{f}(\mathbf{p}, \mathbf{v}, \lambda, t)$ zależy bezpośrednio od mnożników $\lambda(t)$ (poprzez siły tarcia pomiędzy kołem i szyną). Macierz masowa oznaczona jest przez $\mathbf{M}(\mathbf{p})$.

Do równań więzów (3) wprowadzony zostaje „,sprężysty kontakt hertzowski” (element sprężysto-tłumiący). Pozwala to nadać równaniom ruchu postać zwyczajnych równań różniczkowych i umożliwia badanie zjawiska wykolejenia. W zwyczajnych równaniach różniczkowych ruchu siły normalne są siłami czynnymi, wynikającymi z charakterystyk sprężystotłumiących pomiędzy kołem i szyną.

\section{ZAKRES BADAŃ SYMULACYJNYCH}

Zakres badań symulacyjnych dotyczących dynamicznych właściwości modelu wagonu pasażerskiego z wózkami asymetrycznymi zawężono do oceny zagrożenia wykolejeniem na torze zakrzywionym. Zrealizowane zostały dwa scenariusze obliczeń:

I. Dla znanej prędkości maksymalnej badanego modelu wagonu $\mathrm{w}$ ruchu po torze prostym. Wyznaczone zostały wartości minimalnego promienia łuku oraz przechyłki toru, gwarantujące bezpieczny przejazd modelu po torze zakrzywionym z prędkością maksymalną. Następnie wykonano obliczenia dynamiczne na torze zakrzywionym o wyznaczonych parametrach.

II. Przy założeniu, że pojazd poruszać się będzie po najmniejszym promieniu łuku w kategoriach linii nowo zbudowanej lub zmodernizowanej, określona została dopuszczalna prędkość oraz wartość przechyłki dla toru zakrzywionego. Następnie wykonano obliczenia dynamiczne na torze zakrzywionym o wyznaczonych parametrach.

Pierwszy ze scenariuszy wymagał zbadania stateczności modelu wagonu na torze prostym w celu wyznaczenia prędkości krytycznej, dającej podstawy do ustalenia prędkości maksymalnej. Problem badania stateczności ruchu został potraktowany czysto informacyjnie. Główną uwagę skupiono natomiast na oce- nie własności dynamicznych pojazdu w kategoriach niebezpieczeństwa związanego z wykolejeniem podczas przejazdu przez łuki odwrotne toru zakrzywionego.

Przez wykolejenie rozumie się sytuację, w której zestaw kół prowadzony przez tor kolejowy, wspina się na główkę szyny i wyjeżdża poza tor, co najczęściej występuje wtedy, gdy na koło działa duża siła poprzeczna przy znacznie zredukowanym obciążeniu pionowym.

Wśród narzędzi symulacyjnych, zweryfikowanych przez pomiary na obiektach rzeczywistych, wymienić należy program NUCARS, przygotowany do modelowania pojazdów szynowych i badania ich dynamiki w stanach nieustalonych $\mathrm{i}$ ustalonych. Włączony on został do Specyfikacji M-1001 Stowarzyszenia Kolei Amerykańskich (AAR), jako tzw. „Chapter XI”.

Metody stosowane w Europie opierają się na wynikach otrzymywanych $\mathrm{z}$ testów statycznych, dynamicznych oraz nieliniowych symulacji. Nieliniowe symulacje wykonywane są w celu określenia skłonności pojazdu do wykolejenia, gdy porusza się on po torze rzeczywistym w warunkach ekstremalnych. Przykładami najbardziej znanych narzędzi symulacyjnych stosowanych w Europie i na świecie są programy: MEDYNA, VAMPIRE oraz ADAMS/RAIL.

$\mathrm{Na}$ przestrzeni ostatnich kilkudziesięciu lat stosowano wiele kryteriów ograniczających możliwość powstawania wykolejenia, będącego wynikiem wspinania się koła na szynę. Kryterium Nadala [3], związane z oceną stosunku sił Y/Q dla pojedynczego koła, wprowadzone zostało w 1908 roku i ciagle jest stosowane. Równanie wyprowadzone przez Nadala opisuje równowagę sił w płaszczyźnie styku koła z szyną. Niebezpieczeństwo wykolejenia może pojawić się wówczas, gdy suma składowych na kierunek pionowy, pochodzacych od sił normalnych oraz od sił stycznych w punkcie styku koła z szyną, osiąga wartość zbliżoną do pionowego obciążenia przypadającego na dane koło.

W testach przeprowadzanych na pojazdach szynowych i laboratoryjnych testach stanowiskowych, często stwierdzano brak wykolejenia pomimo przekroczenia dopuszczalnej wartości Y/Q. Wykorzystując te obserwacje Koleje Japońskie (JNR) oraz General Motors (oddział EMD) zaproponowały zwiększenie limitu Y/Q dla pojedynczego koła w sytuacji, gdy czas występowania badanej wartości Y/Q jest krótki. W projekcie zrealizowanym przez AAR użyty został specjalnie skonstruowany pojazd TLV, wyposażony w dodatkowy wózek (umieszczony pod ramą, w środkowej części pojazdu) umożliwiający weryfikację teorii w sytuacji, gdy do wykolejenia dochodzi w wyniku wspinania się koła na szynę. Zestawy kół tego wózka obciążane są w kierunku pionowym i poziomym przez zespół siłowników hydraulicznych, co pozwala doprowadzić do wykolejenia zestawu pomiaro- 
wego. Układ pomiaro wy umożliwia również nastawienie odpowiednich wartości kątów nabiegania, co pozwala badać wpływ tych wielkości na wykolejenie. Konwencję dodatniego znaku kąta nabiegania przedstawiono na rys.5.

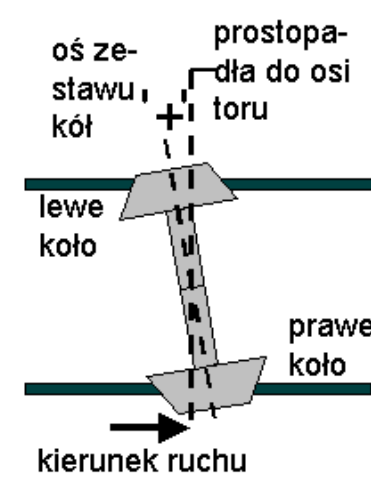

Rys.5 Konwencja dodatniego znaku kąta nabiegania

Rezultaty obliczeń symulacyjnych (uzyskane z programu NUCARS) wykazały istotny wpływ kata nabiegania koła na szynę w procesie wykolejenia (rys.6). Wyniki te pokazują, że dla dużych kątów nabiegania zestawu kół, do wykolejenia dochodzi przy wartości $|\mathrm{Y} / \mathrm{Q}|$ wynikającej z równania Nadala. Jednakże dla mniejszych i ujemnych kątów nabiegania, taka sytuacja zachodzi przy znacznie wyższej wartości |Y/Q|. Tak więc $\mathrm{z}$ punktu widzenia bezpieczeństwa ruchu, informacja na temat kąta nabiegania kół na szyny pełni bardzo ważną rolę.

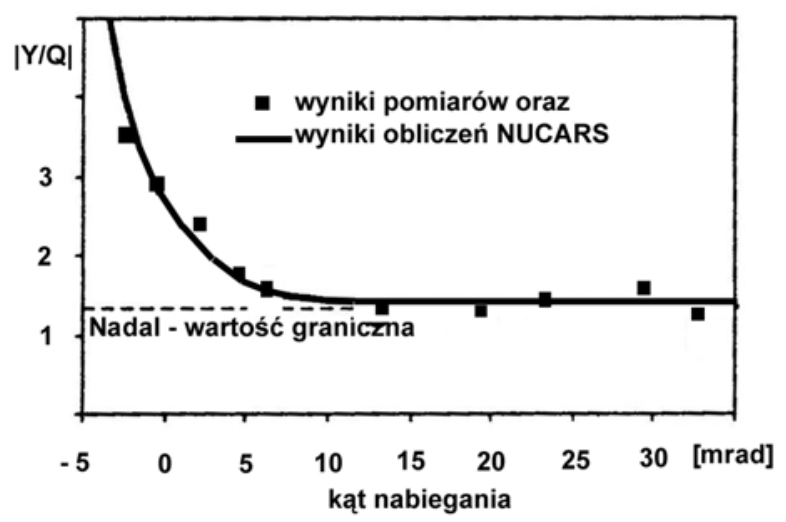

Rys.6 Wpływ kąta nabiegania na wartości |Y/Q|, przy których dochodzi do wykolejenia w wyniku wspinania się obrzeża koła na szynę [3]

W oparciu o testy wykonane w warunkach rzeczywistych (pojazd LTV) oraz obliczenia numeryczne (program NUCARS) przyjęto, że graniczna wartość dla Y/Q na pojedynczym kole powinna wynosić 1, jeśli kąt nabiegania koła na szynę jest większy od 5 mrad [3] . Jednakże, aby dopuścić większe wartości $\mathrm{Y} / \mathrm{Q}$ przy mniejszych kątach nabiegania, zaproponowano następujące kryterium dla pojedynczego koła:
$\frac{\mathrm{Y}}{\mathrm{Q}}<1.0$, jeśli kąt nabiegania $\varphi>5[\mathrm{mrad}]$

$\frac{Y}{Q}<\frac{12}{\varphi+7}$, jeśli kąt nabiegania $\varphi<5 \mathrm{mrad}$

$\frac{\mathrm{Y}}{\mathrm{Q}}<1.0$, gdy nie dokonuje się pomiaru

kąta nabiegania.

Program Adams/Rail oblicza wartości kątów nabiegania kół na szyny oraz stosunki sił Y/Q. Przedmiotem badań pozostawał również wskaźnik zużycia kół i szyn, wyznaczany $\mathrm{w}$ programie $\mathrm{w}$ oparciu o zależność:

$$
\mathrm{W}_{\mathrm{Z}}=\mathrm{T}_{\mathrm{X}} \cdot \vartheta_{\mathrm{X}}+\mathrm{T}_{\mathrm{y}} \cdot \vartheta_{\mathrm{y}}+\Phi \cdot \mathrm{M}_{\mathrm{z}}
$$

gdzie:

$\vartheta_{\mathrm{X}}, \vartheta_{\mathrm{y}}, \Phi$ - poślizg wzdłużny, poślizg poprzeczny oraz spin w obszarze styku koła i szyny,

$\mathrm{T}_{\mathrm{X}}, \mathrm{T}_{\mathrm{y}}$-siła styczna odpowiednio na kierunku wzdłużnym i poprzecznym,

$\mathrm{M}_{\mathrm{z}} \quad$ - moment wynikający $\mathrm{z}$ istnienia spinu,

$\mathrm{W}_{\mathrm{Z}}$ - wskaźnik zużycia, oznaczający pracę sił stycznych na jednostkowej drodze przebytej przez koło.

\section{PARAMETRY OBLICZENIOWE MODELU WAGONU}

\subsection{Parametry geometryczne}

$\mathrm{Na}$ podstawie wcześniejszych badań ustalono, że najkorzystniejsze rozwiązanie w kategoriach dużej prędkości krytycznej wagonu można uzyskać, gdy średnice kół $\mathrm{w}$ wózku różnią się pomiędzy sobą co najmniej dwukrotnie [6]. W analizowanym przypadku wagonu pasażerskiego przyjęto do obliczeń średnice nominalne równe odpowiednio $1 \mathrm{~m}$ dla koła dużego oraz $0.5 \mathrm{~m}$ dla koła małego. Pozostałe parametry konstrukcyjne w znacznej części zaczerpnięto $\mathrm{z}$ [5]. Oznaczenia podane na rys.7, 8 oraz 9 odnoszą się do wózka symetrycznego, natomiast wymiary geometryczne przedstawione $\mathrm{w}$ tabelach dotyczą konstrukcji asymetrycznej.

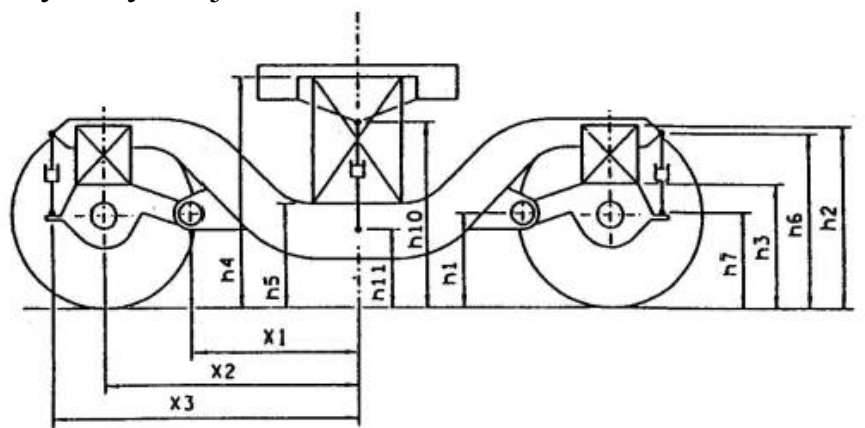

Rys.7 Ważniejsze wymiary dotyczące rozmieszczenia elementów zawieszenia w przekroju wzdłużnym wózka [5] 


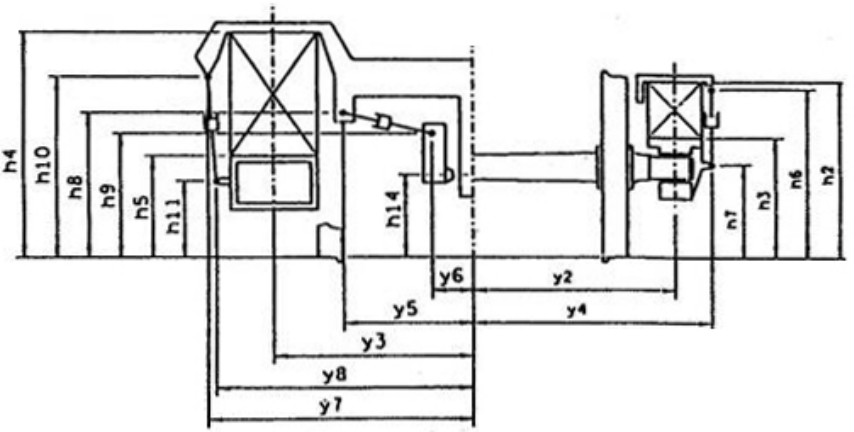

Rys.8 Ważniejsze wymiary dotyczące rozmieszczenia elementów zawieszenia w przekroju poprzecznym wózka $\lceil 5\rceil$

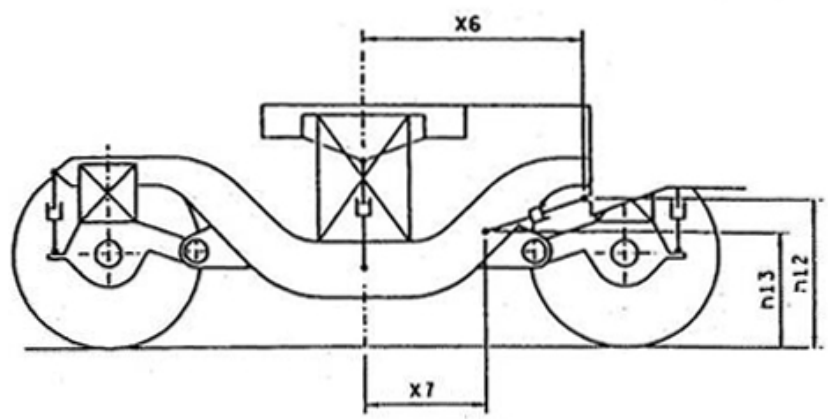

Rys.9 Ważniejsze wymiary dotyczące mocowania tłumików wężykowania [5]

Punkty mocowania ramienia wahacza do ramy wózka

Tabela 1

\begin{tabular}{|l|c|c|}
\hline \multicolumn{1}{|c|}{ Opis punktu mocowania } & $\begin{array}{c}\text { Ozna- } \\
\text { czenie }\end{array}$ & $\begin{array}{c}\text { Wymiar } \\
{[\mathrm{mm}]}\end{array}$ \\
\hline $\begin{array}{l}\text { Punkt mocowania do ramy w kie- } \\
\text { runku wzdłużnym }\end{array}$ & $\mathrm{x}_{1}$ & 830 \\
\hline $\begin{array}{l}\text { Punkt mocowania do ramy w kie- } \\
\text { runku poprzecznym }\end{array}$ & $\mathrm{y}_{2}$ & 1000 \\
\hline $\begin{array}{l}\text { Odległość od poziomu główki szy- } \\
\text { ny (duże koło/małe koło) }\end{array}$ & $\mathrm{h}_{1}$ & $500 / 250$ \\
\hline
\end{tabular}

\section{Punkty osadzenia sprężyn zawieszenia 1 stopnia}

Tabela 2

\begin{tabular}{|l|c|c|}
\hline \multicolumn{1}{|c|}{ Opis punktu osadzenia } & $\begin{array}{c}\text { Ozna- } \\
\text { czenie }\end{array}$ & Wymiar [mm] \\
\hline $\begin{array}{l}\text { Punkt osadzenia na korpusie } \\
\text { łożyska osiowego w kierun- } \\
\text { ku wzdłużnym }\end{array}$ & $\mathrm{x}_{2}$ & 1250 \\
\hline $\begin{array}{l}\text { Punkt osadzenia na korpusie } \\
\text { łż̇yska osiowego w kierun- } \\
\text { ku poprzecznym }\end{array}$ & $\mathrm{y}_{2}$ & 1000 \\
\hline $\begin{array}{l}\text { Odległość od poziomu głów- } \\
\text { ki szyny do zetknięcia z ramą } \\
\text { wózka (duże koło/małe koło) }\end{array}$ & $\mathrm{h}_{2}$ & $1020 / 520$ \\
\hline $\begin{array}{l}\text { Odległość od poziomu głów- } \\
\text { ki szyny do punktu osadzenia } \\
\text { na korpusie łożyska osiowe- } \\
\text { go (duże koło/małe koło) }\end{array}$ & $\mathrm{h}_{3}$ & $760 / 260$ \\
\hline
\end{tabular}

Punkty osadzenia sprężyn zawieszenia 2 stopnia

Tabela 3

\begin{tabular}{|l|c|c|}
\hline \multicolumn{1}{|c|}{ Opis punktu osadzenia } & $\begin{array}{c}\text { Ozna- } \\
\text { czenie }\end{array}$ & $\begin{array}{c}\text { Wymiar } \\
{[\mathrm{mm}]}\end{array}$ \\
\hline $\begin{array}{l}\text { Odległość od środka ramy w kie- } \\
\text { runku poprzecznym }\end{array}$ & $\mathrm{y}_{3}$ & 1000 \\
\hline $\begin{array}{l}\text { Odległość od poziomu główki szy- } \\
\text { ny do zetknięcia z nadwoziem }\end{array}$ & $\mathrm{h}_{4}$ & 1130 \\
\hline $\begin{array}{l}\text { Odległość od poziomu główki szy- } \\
\text { ny do punktu osadzenia na ramie } \\
\text { wózka }\end{array}$ & $\mathrm{h}_{5}$ & 520 \\
\hline
\end{tabular}

Punkty mocowania tlumików pionowych zawieszenia 1 stopnia

Tabela 4

\begin{tabular}{|l|c|c|}
\hline \multicolumn{1}{|c|}{ Opis punktu mocowania } & $\begin{array}{c}\text { Ozna- } \\
\text { czenie }\end{array}$ & $\begin{array}{c}\text { Wymiar } \\
{[\mathrm{mm}]}\end{array}$ \\
\hline $\begin{array}{l}\text { Punkt mocowania na korpusie łoży- } \\
\text { ska osiowego w kierunku wzdłuż- } \\
\text { nym }\end{array}$ & $\mathrm{x}_{3}$ & 1550 \\
\hline $\begin{array}{l}\text { Punkt mocowania na korpusie łoży- } \\
\text { ska osiowego w kierunku poprzecz- } \\
\text { nym }\end{array}$ & $\mathrm{y}_{4}$ & 1000 \\
\hline $\begin{array}{l}\text { Odległość od poziomu główki szy- } \\
\text { ny do zetknięcia z ramą wózka (du- } \\
\text { że koło/małe koło) }\end{array}$ & $\mathrm{h}_{6}$ & $1020 / 520$ \\
\hline $\begin{array}{l}\text { Odległość od poziomu główki szy- } \\
\text { ny do punktu osadzenia na korpusie } \\
\text { łożyska osiowego (duże koło/małe } \\
\text { koło) }\end{array}$ & $\mathrm{h}_{7}$ & $760 / 260$ \\
\hline
\end{tabular}

Punkty mocowania tlumików poprzecznych zawieszenia 2 stopnia

Tabela 5

\begin{tabular}{|l|c|c|}
\hline \multicolumn{1}{|c|}{ Opis punktu mocowania } & $\begin{array}{c}\text { Ozna- } \\
\text { czenie }\end{array}$ & $\begin{array}{c}\text { Wymiar } \\
{[\mathrm{mm}]}\end{array}$ \\
\hline $\begin{array}{l}\text { Odległość od środka ramy do } \\
\text { punktu mocowania na nadwoziu } \\
\text { (kierunek poprzeczny) }\end{array}$ & $\mathrm{y}_{5}$ & 665 \\
\hline $\begin{array}{l}\text { Odległość od środka ramy do } \\
\text { punktu mocowania na ramie wóz- } \\
\text { ka (kierunek poprzeczny) }\end{array}$ & $\mathrm{y}_{6}$ & 230 \\
\hline $\begin{array}{l}\text { Odległość od poziomu główki } \\
\text { szyny do połączenia z nadwoziem } \\
\text { (duże koło/małe koło) }\end{array}$ & $\mathrm{h}_{8}$ & $830 / 330$ \\
\hline $\begin{array}{l}\text { Odległość od poziomu główki } \\
\text { szyny do połączenia z ramą wózka } \\
\text { (duże koło/małe koło) }\end{array}$ & $\mathrm{h}_{9}$ & $730 / 230$ \\
\hline
\end{tabular}

Punkty mocowania tlumików pionowych zawieszenia 2 stopnia

Tabela 6

\begin{tabular}{|l|c|c|}
\hline \multicolumn{1}{|c|}{ Opis punktu mocowania } & $\begin{array}{c}\text { Ozna- } \\
\text { czenie }\end{array}$ & $\begin{array}{c}\text { Wymiar } \\
{[\mathrm{mm}]}\end{array}$ \\
\hline $\begin{array}{l}\text { Odległość od środka ramy do } \\
\text { punktu mocowania na nadwoziu } \\
\text { (kierunek poprzeczny) }\end{array}$ & $\mathrm{y}_{7}$ & 1335 \\
\hline $\begin{array}{l}\text { Odległość od środka ramy do } \\
\text { punktu mocowania na ramie wóz- } \\
\text { ka (kierunek poprzeczny) }\end{array}$ & $\mathrm{y}_{8}$ & 1300 \\
\hline $\begin{array}{l}\text { Odległość od poziomu główki } \\
\text { szyny do połączenia z nadwoziem }\end{array}$ & $\mathrm{h}_{10}$ & 1010 \\
\hline $\begin{array}{l}\text { Odległość od poziomu główki } \\
\text { szyny do połączenia z ramą wózka } \\
\text { (duże koło/małe koło) }\end{array}$ & $\mathrm{h}_{11}$ & 450 \\
\hline
\end{tabular}


Punkty mocowania tłumików wężykowania zawieszenia 2 stopnia

\begin{tabular}{|l|c|c|}
\hline \multicolumn{1}{|c|}{ Opis punktu mocowania } & $\begin{array}{c}\text { Ozna- } \\
\text { czenie }\end{array}$ & $\begin{array}{c}\text { Wymiar } \\
{[\mathrm{mm}]}\end{array}$ \\
\hline $\begin{array}{l}\text { Odległość od środka ramy do } \\
\text { punktu mocowania na nadwoziu } \\
\text { (kierunek wzdłużny) }\end{array}$ & $\mathrm{x}_{6}$ & 1106 \\
\hline $\begin{array}{l}\text { Odległość od środka ramy do } \\
\text { punktu mocowania na ramie wóz- } \\
\text { ka (kierunek wzdłużny) }\end{array}$ & $\mathrm{x}_{7}$ & 230 \\
\hline $\begin{array}{l}\text { Odległość od środka ramy do } \\
\text { punktu mocowania na nadwo- } \\
\text { ziu/wózku }\end{array}$ & $\mathrm{y}_{9}$ & $1410 /$ \\
\hline $\begin{array}{l}\text { Odległość od poziomu główki } \\
\text { szyny do połączenia z nadwoziem }\end{array}$ & $\mathrm{h}_{12}$ & 700 \\
\hline $\begin{array}{l}\text { Odległość od poziomu główki } \\
\text { szyny do połączenia z ramą wózka }\end{array}$ & $\mathrm{h}_{13}$ & 620 \\
\hline
\end{tabular}

Punkty mocowania ograniczników poprzecznych zawieszenia 2 stopnia

Tabela 8

\begin{tabular}{|l|c|c|}
\hline \multicolumn{1}{|c|}{ Opis punktu mocowania } & $\begin{array}{c}\text { Ozna- } \\
\text { czenie }\end{array}$ & $\begin{array}{c}\text { Wymiar } \\
{[\mathrm{mm}]}\end{array}$ \\
\hline $\begin{array}{l}\text { Odległość od poziomu główki } \\
\text { szyny }\end{array}$ & $\mathrm{h}_{14}$ & 700 \\
\hline
\end{tabular}

Do obliczeń przyjęto bazę nadwozia wynoszącą $19 \mathrm{~m}$ oraz położenie środka ciężkości nadwozia na wysokości $1.8 \mathrm{~m}$ od poziomu główek szyn [5].

\subsection{Parametry masowe}

Masy oraz momenty bezwładności poszczególnych elementów wagonu odpowiadają wartościom cytowanym w [1] - tabela 9. W przypadku kół o małej średnicy program Adams/Rail automatycznie oblicza masę zestawu kół i momenty bezwładności.
Masy i momenty bezwladności elementów wagonu

Tabela 9

\begin{tabular}{|l|c|c|c|c|}
\hline \multirow{2}{*}{ Element } & \multirow{2}{*}{$\begin{array}{c}\text { Masa } \\
{[\mathrm{kg}]}\end{array}$} & \multicolumn{3}{|c|}{ Moment bezwładności $\left[\mathrm{kg} \mathrm{m}^{2}\right]$} \\
\cline { 3 - 5 } & $\mathrm{I}_{\mathrm{x}}$ & $\mathrm{I}_{\mathrm{y}}$ & $\mathrm{I}_{\mathrm{z}}$ \\
\hline $\begin{array}{l}\text { Zestaw kół } \mathrm{z} \\
\text { łożyskami } \\
\text { (duże koła) }\end{array}$ & 1500 & 810 & 112 & 810 \\
\hline $\begin{array}{l}\text { Ramię wa- } \\
\text { hacza }\end{array}$ & 155 & 2.1 & 5.6 & 5.6 \\
\hline $\begin{array}{l}\text { Rama wóz- } \\
\text { ka }\end{array}$ & 2615 & 1722 & 1476 & 3067 \\
\hline Nadwozie & 32000 & 56800 & 1970000 & 1970000 \\
\hline
\end{tabular}

\subsection{Sztywności kierunkowe}

Sztywności kierunkowe elementów zawieszenia dobrane zostały pod kątem uzyskania wysokiej prędkości krytycznej wagonu $\mathrm{w}$ ruchu po torze prostym. $\mathrm{W}$ związku z tym różnią się one od zalecanych w [1], jednak zbliżone są do wartości zastosowanych $\mathrm{w}$ prototypowym wózku BKW200 (tabela 10).

Sztywności kierunkowe elementów zawieszenia

Tabela 10

\begin{tabular}{|l|c|c|c|}
\hline \multirow{2}{*}{ Element } & \multicolumn{3}{|c|}{ Sztywność kierunkowa [N/m] } \\
\cline { 2 - 4 } & $\mathrm{K}_{\mathrm{x}}$ & $\mathrm{K}_{\mathrm{y}}$ & $\mathrm{K}_{\mathrm{z}}$ \\
\hline $\begin{array}{l}\text { Przegub metalowo- } \\
\text { gumowy ramienia } \\
\text { wahacza }\end{array}$ & $30 \cdot 10^{6}$ & $80 \cdot 10^{6}$ & $30 \cdot 10^{6}$ \\
\hline $\begin{array}{l}\text { Sprężyna zawie- } \\
\text { szenia 1 stopnia }\end{array}$ & $0.35 \cdot 10^{6}$ & $0.35 \cdot 10^{6}$ & $0.20 \cdot 10^{6}$ \\
\hline $\begin{array}{l}\text { Sprężyna zawie- } \\
\text { szenia 2 stopnia }\end{array}$ & $3.8 \cdot 10^{6}$ & $3.8 \cdot 10^{6}$ & $1.2 \cdot 10^{6}$ \\
\hline
\end{tabular}

W tabelach od 11 do 15 przedstawiono charakterystyki ograniczników poprzecznych oraz thumików zawieszenia na 1 i 2 stopniu [5].

Charakterystyka ograniczników poprzecznych zawieszenia 2 st. (symetryczna)

Tabela 11

\begin{tabular}{|c|c|c|c|c|c|c|c|c|c|c|c|}
\hline Przemieszczenie & {$[\mathrm{m}]$} & 0 & 0.025 & 0.030 & 0.035 & 0.040 & 0.045 & 0.050 & 0.055 & 0.060 & 0.065 \\
\hline Siła & {$[\mathrm{kN}]$} & 0 & 0.20 & 0.60 & 1.76 & 3.73 & 6.87 & 11.58 & 17.17 & 29.2 & 230 \\
\hline
\end{tabular}

Charakterystyka tlumików pionowych zawieszenia 1 st. (symetryczna)

Tabela 12

\begin{tabular}{|c|c|l|c|c|c|c|c|c|c|c|}
\hline Prędkość & {$[\mathrm{m} / \mathrm{s}]$} & 0 & 0.04 & 0.09 & 0.16 & 0.28 & 1.0 & 10.0 & 20.0 & 50.0 \\
\hline Siła & {$[\mathrm{kN}]$} & 0 & 0.1 & 0.2 & 0.3 & 0.4 & 1.0 & 8.5 & 16.8 & 42.0 \\
\hline
\end{tabular}

Charakterystyka tlumików pionowych zawieszenia 2 st. (symetryczna)

Tabela 13

\begin{tabular}{|c|c|c|c|c|c|c|c|c|}
\hline Prędkość & {$[\mathrm{m} / \mathrm{s}]$} & 0 & 0.015 & 0.08 & 0.26 & 1.0 & 10.0 & 20.0 \\
\hline Siła & {$[\mathrm{kN}]$} & 0 & 1.0 & 2.0 & 3.0 & 7.1 & 57.1 & 112.6 \\
\hline
\end{tabular}

Charakterystyka tlumików poprzecznych zawieszenia 2 st. (symetryczna)

Tabela 14

\begin{tabular}{|c|c|c|c|c|c|c|c|c|c|}
\hline Prędkość & {$[\mathrm{m} / \mathrm{s}]$} & 0 & 0.03 & 0.07 & 0.15 & 0.305 & 1.0 & 10.0 & 20.0 \\
\hline Siła & {$[\mathrm{kN}]$} & 0 & 1.0 & 2.0 & 3.0 & 4.0 & 8.5 & 66.5 & 131.0 \\
\hline
\end{tabular}

Charakterystyka tlumików weżykowania zawieszenia 2 st. (symetryczna)

Tabela 15

\begin{tabular}{|c|c|c|c|c|c|c|c|c|c|}
\hline Prędkość & {$[\mathrm{m} / \mathrm{s}]$} & 0 & 0.04 & 0.055 & 0.11 & 0.14 & 1.0 & 10.0 & 20.0 \\
\hline Siła & {$[\mathrm{kN}]$} & 0 & 7.0 & 8.0 & 10.0 & 11.0 & 39.7 & 339.7 & 673.0 \\
\hline
\end{tabular}




\section{DANE WEJŚCIOWE DO OBLICZEŃ DY- NAMICZNYCH}

\subsection{Wyznaczenie prędkości maksymalnej}

Przed rozpoczęciem badań symulacyjnych na torze zakrzywionym wyznaczono prędkości krytyczne w ruchu po torze prostym dla dwóch przypadków: wagonu pasażerskiego $\mathrm{z}$ wózkami symetrycznymi (promienie nominalne kół równe $0.5 \mathrm{~m}$ ) oraz wagonu pasażerskiego z wózkami asymetrycznymi (promienie nominalne kół równe odpowiednio $0.5 \mathrm{~m}$ i $0.25 \mathrm{~m}$ ). Stwierdzono, że konstrukcja symetryczna umożliwia jazdę z prędkością $58 \mathrm{~m} / \mathrm{s}$, co odpowiada około 208 $\mathrm{km} / \mathrm{h}$ (rys.10). Przypadek asymetryczny gwarantuje natomiast prędkość krytyczną rzędu $42 \mathrm{~m} / \mathrm{s}$, co daje około $150 \mathrm{~km} / \mathrm{h}$ (rys.11). Prędkość krytyczna identyfikowana jest jako prędkość, przy której współczynnik wythumiania drgań zmienia znak $\mathrm{z}$ dodatniego na ujemny.

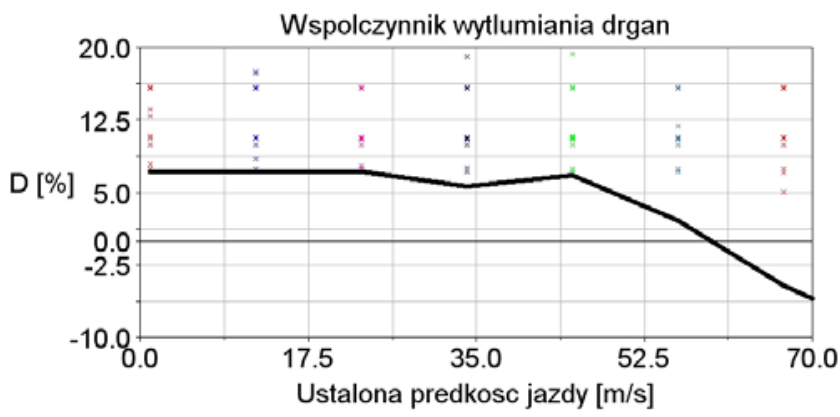

Rys.10 Zmienność współczynnika wytłumiania drgań w funkcji ustalonej prędkości jazdy wagonu z wózkami symetrycznymi po torze prostym - Adams/Rail

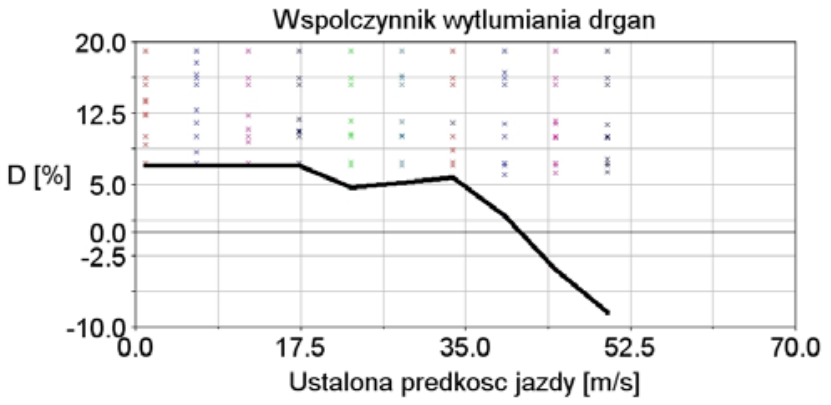

Rys.11 Zmienność współczynnika wytłumiania drgań w funkcji ustalonej prędkości jazdy wagonu z wózkami asymetrycznymi po torze prostym - Adams/Rail

\subsection{Parametry toru zakrzywionego}

W pierwszej kolejności zrealizowano scenariusz I, wyznaczając minimalny promień łuku dla prędkości maksymalnej. Wykorzystany został $\mathrm{w}$ tym celu wzór cytowany w [1] przy założeniu, że po tych samych torach poruszać się będą zarówno wagony pasażerskie, jak i towarowe:

$$
\mathrm{R}_{\min }=\left(\mathrm{v}_{\mathrm{p}}^{2}-\mathrm{v}_{\mathrm{t}}^{2}\right) /\left(\mathrm{a}_{\mathrm{dop}}+\mathrm{a}_{\mathrm{t}}\right)
$$

przy czym $\mathrm{v}_{\mathrm{p}}, \mathrm{v}_{\mathrm{t}}$ oznaczają kolejno: prędkość maksymalną wagonu pasażerskiego oraz towarowego, natomiast $\mathrm{a}_{\mathrm{dop}}, \mathrm{a}_{\mathrm{t}}$ - wartości niezrównoważonych przyśpieszeń na torze zakrzywionym. W warunkach polskich przyjmuje się: $\mathrm{v}_{\mathrm{t}}=22 \mathrm{~m} / \mathrm{s}, \mathrm{a}_{\mathrm{dop}}=0.6 \mathrm{~m} / \mathrm{s}^{2}$ oraz $\mathrm{a}_{\mathrm{t}}=0.3 \mathrm{~m} / \mathrm{s}^{2}-[1]$, co przy znanej prędkości $\mathrm{v}_{\mathrm{p}}=150 \mathrm{~km} / \mathrm{h}$, prowadzi do $\mathrm{R}_{\min } \approx 1200 \mathrm{~m}$. Wielkość przechyłki toru obliczono w oparciu o wzór [1]:

$$
\mathrm{h}=11.8 \cdot \mathrm{v}_{\mathrm{p}}^{2} / \mathrm{R}_{\min }-90
$$

Do dalszych obliczeń przyjęto $h_{I}=130 \mathrm{~mm}$.

Przy założeniu, że pojazd poruszać się będzie po najmniejszym promieniu tuku linii nowo zbudowanej lub zmodernizowanej znaczenia lokalnego, przyjęto zgodnie $\mathrm{z}$ [1] $\mathrm{R}_{\min }=500 \mathrm{~m}$. Z zależności

$$
\mathrm{v}_{\max }=4.51 \cdot \sqrt{\mathrm{R}_{\min }[\mathrm{m}]}
$$

wyznaczono wartość prędkości dopuszczalnej dla wagonu na torze o promieniu krzywizny $500 \mathrm{~m}$, uzyskując wartość $100 \mathrm{~km} / \mathrm{h}$. Do obliczeń przyjęto prędkość $25 \mathrm{~m} / \mathrm{s}$. Korzystając ze wzoru (10) określono także wielkość przechyłki, przyjmując $h_{I I}=140 \mathrm{~mm}$.

Wyróżnione dwa przypadki toru zakrzywionego posiadają różne wartości promieni krzywizn oraz różne wartości przechyłki. Cechą wspólną tych torów jest ich układ i długość całkowita wynosząca $600 \mathrm{~m}$. Tory ukształtowane zostały w formę tzw. łuków odwrotnych, przy czym wagon rozpoczyna bieg na odcinku toru prostego o długości $\mathrm{pr}_{1}=50 \mathrm{~m}$, przechodzi w krzywą przejściową $\mathrm{kp}_{1}=40 \mathrm{~m}$, następnie $\mathrm{w}$ prawy łuk o długości $\ell_{1}=50 \mathrm{~m}, \mathrm{w}$ krzywą przejściową $\mathrm{kp}_{2}=40 \mathrm{~m}$, odcinek toru prostego (wstawka o długości $\mathrm{w}=30 \mathrm{~m}$ ), następnie $\mathrm{w}$ krzywą przejściową $\mathrm{kp}_{3}=40 \mathrm{~m}$, $\mathrm{w}$ lewy łuk o długości $\bigsqcup_{2}=50 \mathrm{~m}$, krzywą przejściową $\mathrm{kp}_{4}=40 \mathrm{~m}$ i kończy bieg na odcinku toru prostego $\mathrm{pr}_{2}=260 \mathrm{~m}$. Długości wstawki toru prostego oraz krzywych przejściowych (krzywe trzeciego stopnia) obliczone zostały w oparciu o zalecenia podane w [1]. W obliczeniach tor traktowany był jako sztywny $\mathrm{i}$ gładki.

\section{WYNIKI OBLICZEŃ DYNAMICZNYCH NA TORZE ZAKRZYWIONYM}

W świetle przedstawionych wcześniej uwag najbardziej istotne wyniki obliczeń symulacyjnych dotyczą kątów styku, kątów nabiegania, stosunku sił Y/Q oraz wskaźników zużycia kół i szyn. Z punktu widzenia bezpieczeństwa ruchu decydujące znaczenie ma zachowanie się koła prowadzącego $\mathrm{w}$ zestawie prowadzącym wózka. $Z$ tego powodu prezentowane wyniki odnoszą się do tych właśnie kół w wózku prowadzącym. Wyniki obliczeń, uzyskane dla wagonu pasażerskiego $\mathrm{z}$ wózkami asymetrycznymi (rysunki $17,18,19,20,21$ i 22), zestawiono $\mathrm{z}$ wynikami uzy- 
skanymi dla wagonu z wózkami symetrycznymi (rysunki 12, 13, 14, 15, 16), których koła posiadały promienie nominalne równe $0.5 \mathrm{~m}$. W każdym $\mathrm{z}$ tych przypadków rozpatrywano scenariusz I $(\mathrm{R}=1200 \mathrm{~m}$, $\mathrm{v}=40 \mathrm{~m} / \mathrm{s})$ oraz scenariusz II $(\mathrm{R}=500 \mathrm{~m}, \mathrm{v}=25 \mathrm{~m} / \mathrm{s})$.

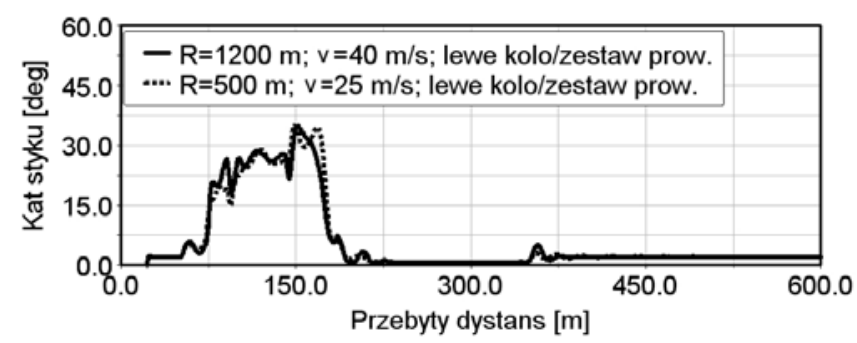

Rys.12 Kąty styku lewego koła w zestawie prowadzącym wózka symetrycznego w funkcji drogi (scenariusz I i II)

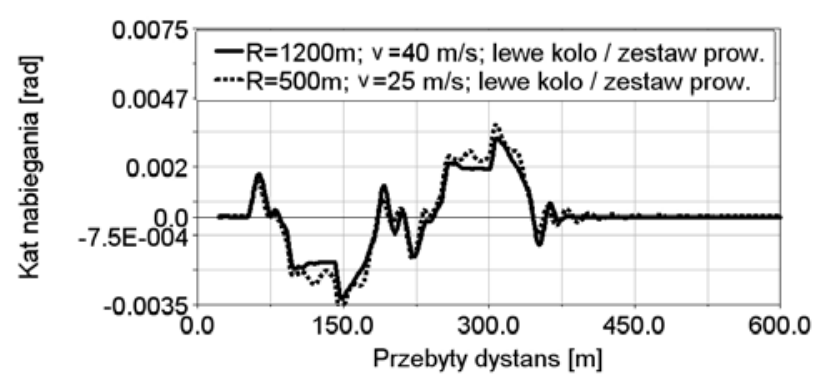

Rys.13 Kąty nabiegania lewego koła w zestawie prowadzącym wózka symetrycznego w funkcji drogi (scenariusz I i II)

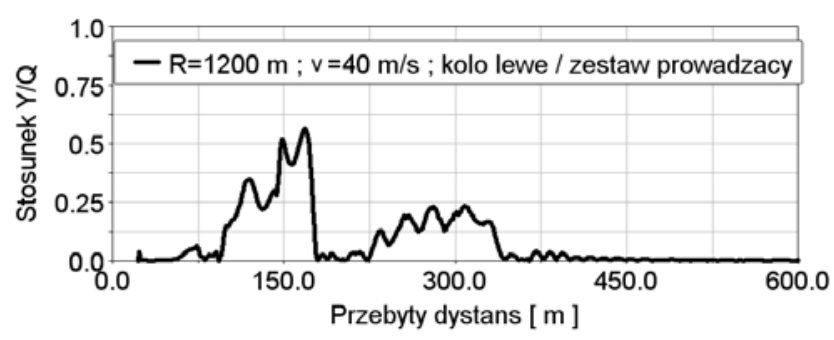

Rys.14 Stosunek $|\mathrm{Y} / \mathrm{Q}|$ dla lewego koła w zestawie prowadzącym wózka symetrycznego w funkcji drogi (scenariusz I)

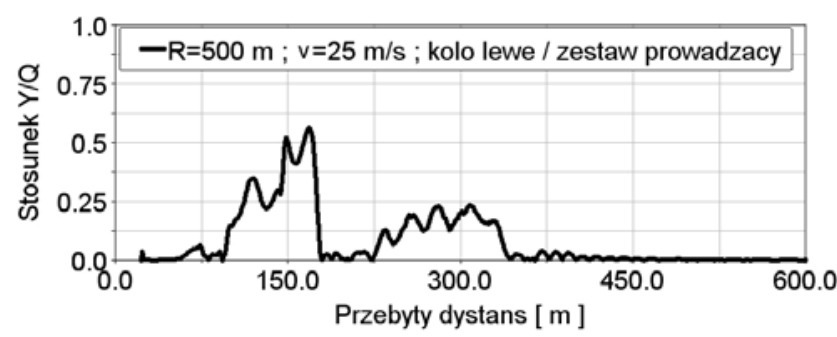

Rys.15 Stosunek |Y/Q| dla lewego koła w zestawie prowadzącym wózka symetrycznego w funkcji drogi (scenariusz II)

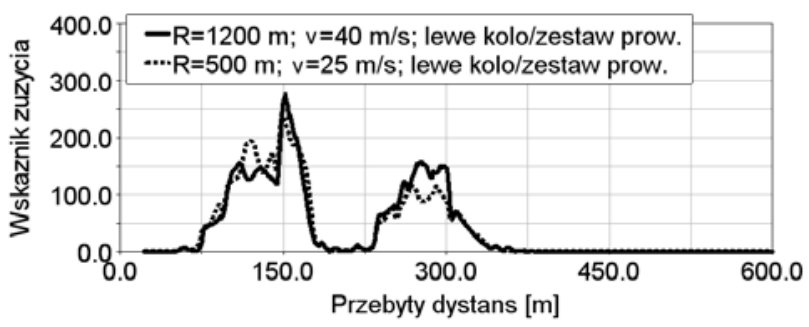

Rys.16 Wskaźnik zużycia w [Nm/m] lewego koła w zestawie prowadzącym wózka symetrycznego w funkcji drogi (scenariusz I i II)

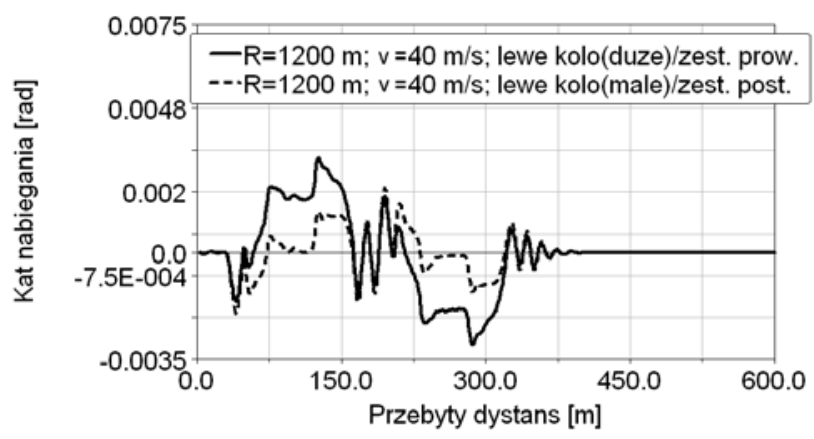

Rys.17 Kąty nabiegania lewego koła w zestawie prowadzącym i postępującym wózka asymetrycznego w funkcji drogi (scenariusz I)

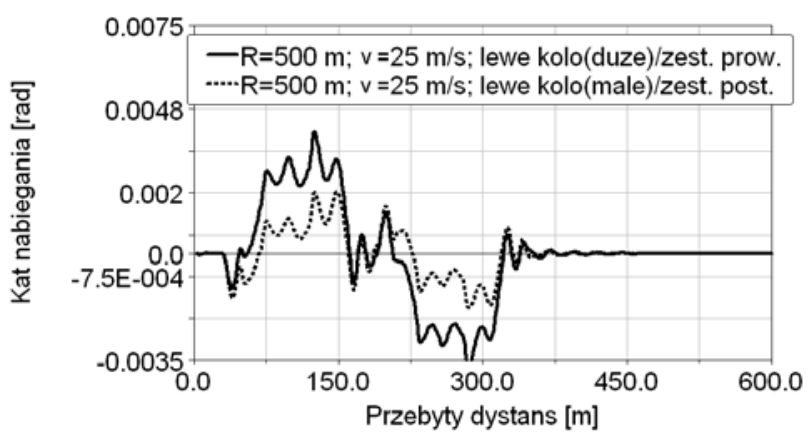

Rys.18 Kąty nabiegania lewego koła w zestawie prowadzącym i postępującym wózka asymetrycznego w funkcji drogi (scenariusz II)

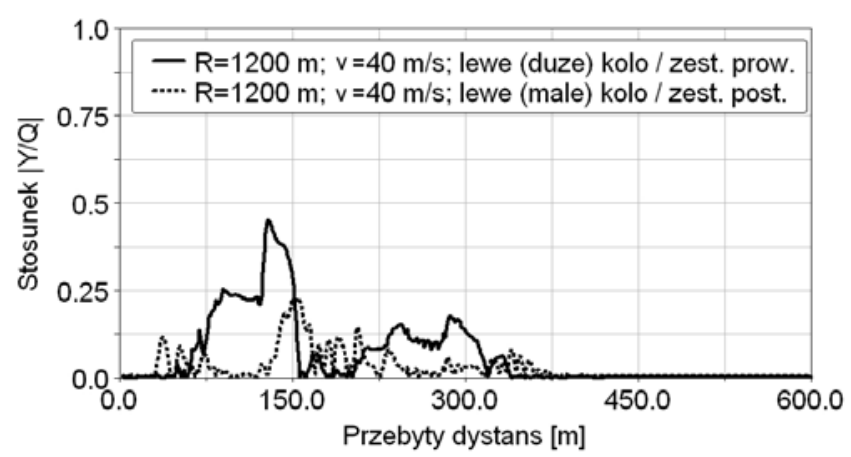

Rys.19 Stosunek |Y/Q| dla lewego koła w zestawie prowadzącym i postępującym wózka asymetrycznego w funkcji drogi (scenariusz I) 


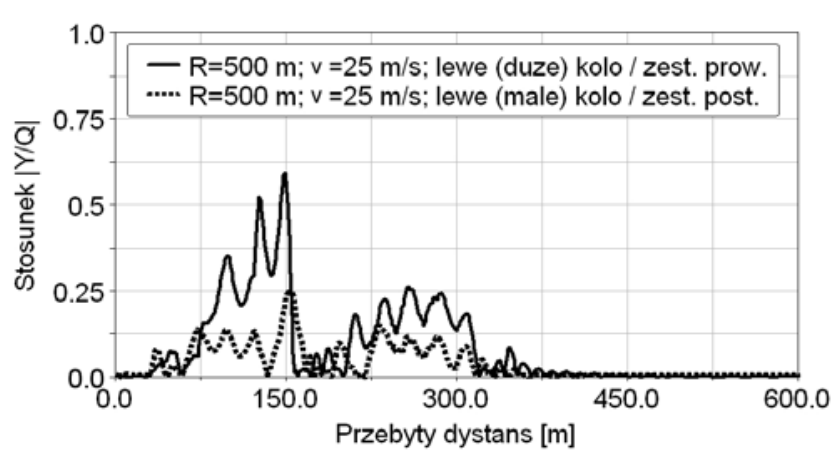

Rys.20 Stosunek |Y/Q| dla lewego koła w zestawie prowadzącym i postępującym wózka asymetrycznego $\mathrm{w}$ funkcji drogi (scenariusz II)

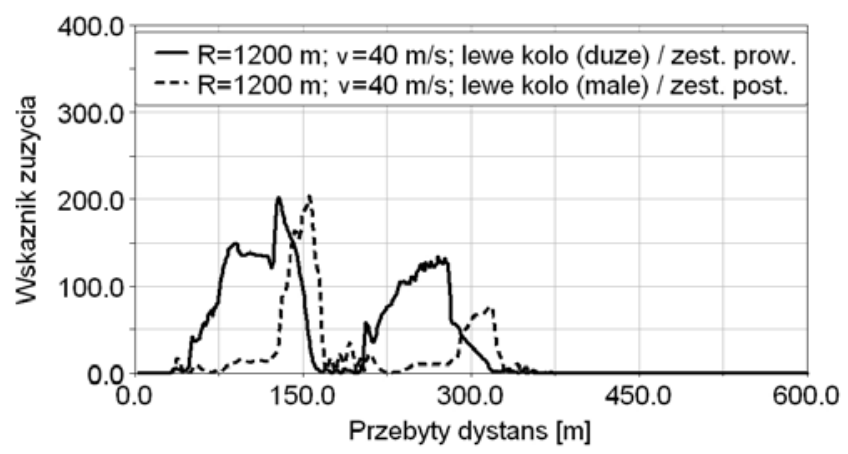

Rys.21 Wskaźniki zużycia w $[\mathrm{Nm} / \mathrm{m}]$ dla lewego koła w zestawie prowadzącym i postępującym wózka asymetrycznego w funkcji drogi (scenariusz I)

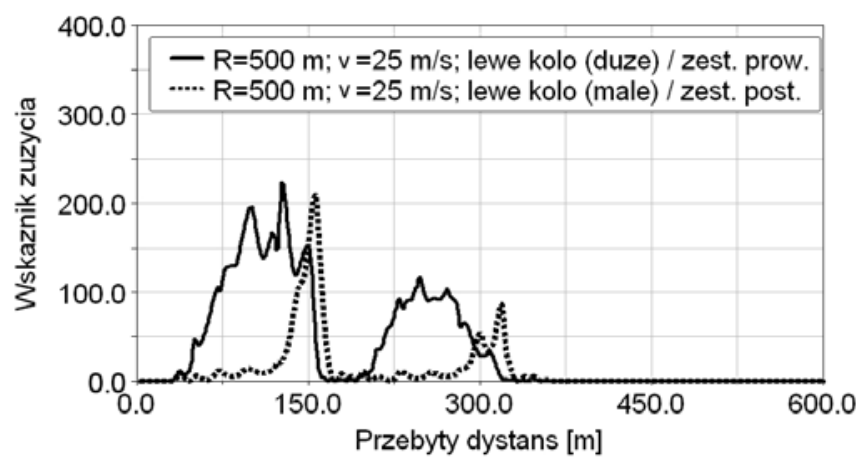

Rys.22 Wskaźniki zużycia w [Nm/m] dla lewego koła w zestawie prowadzącym i postępującym wózka asymetrycznego $\mathrm{w}$ funkcji drogi (scenariusz II)

\section{WNIOSKI}

$\mathrm{Na}$ podstawie uzyskanych wyników obliczeń sformułować można kilka ogólnych wniosków, będących oceną właściwości biegowych wagonu pasażerskiego $\mathrm{z}$ wózkami asymetrycznymi $\mathrm{w}$ porównaniu $\mathrm{z}$ konstrukcją symetryczną:

- wyraźnie widać, że przy takich samych parametrach zawieszenia wagon pasażerski $\mathrm{z}$ wózkami asymetrycznymi posiada mniejszą prędkość krytyczną (w granicach 27\%) niż taki sam wagon $\mathrm{z}$ wózkami symetrycznymi (rys.10 i 11); jednakże jest to w dalszym ciagu wystarczająco wysoka prędkość $(150 \mathrm{~km} / \mathrm{h})$, jeżeli pod uwagę brany będzie ruch lokalny;
- dla obydwu zrealizowanych scenariuszy obliczeniowych kąty nabiegania na torze zakrzywionym nie przekraczają zakresu, który decyduje o bezpieczeństwie (rys.6); zarówno w przypadku konstrukcji symetrycznej, jak i asymetrycznej katy nabiegania nie przekraczają wartości $4.5 \mathrm{mrad}$ (rys.12, 17 i 18);

- najistotniejsze z punktu widzenia bezpieczeństwa ruchu po torze zakrzywionym współczynniki $|\mathrm{Y} / \mathrm{Q}|$ wypadają korzystnie dla wózków asymetrycznych $\mathrm{w}$ przypadku jazdy $\mathrm{z}$ maksymalną prędkością po torze o promieniu krzywizny R=1200 m, (rys.14 i 19); wskaźnik ten dla kół wózka asymetrycznego wynosi 0.45 , natomiast dla wózka symetrycznego jest większy i wynosi 0.6 ;

- podczas jazdy po łukach o promieniach zmniejszonych do $500 \mathrm{~m}$, dla obydwu konstrukcji zarejestrowano podobne wartości $|\mathrm{Y} / \mathrm{Q}|$, na poziomie 0.6 (rys.15 i 20); jak widać są to wartości bezpiecznie odległe od poziomu 1.0;

- interesujące wydaje się być porównanie wskaźników zużycia (rys.16, 21 i 22); w konstrukcji asymetrycznej, dla dużych i małych kół, wskaźnik ten wynosi około $200[\mathrm{Nm} / \mathrm{m}]$ i jest niższy w przybliżeniu o $30 \% \mathrm{w}$ porównaniu $\mathrm{z}$ konstrukcją symetryczną, dla której wskaźnik Wz wynosi około 300 [Nm/m].

Podsumowując, symulacyjne badania modelu wagonu pasażerskiego z wózkami asymetrycznymi wykazały, że konstrukcja tego typu może bezpiecznie poruszać się po torze prostym i zakrzywionym z dużymi prędkościami. Sposób ustawienia wózków pod nadwoziem, pokazany na rys.1, umożliwia również obniżenie podłogi wagonu niemal na całej jego długości, nadając mu cechy wagonu niskopodłogowego.

\section{LITERATURA}

[1] Baluch H.: Optymalizacja ukladów geometrycznych toru. WKE, Warszawa 1983.

[2] Chudzikiewicz A., Droździel J., Sowiński B.: Symulacje wagonu pasażerskiego $w$ zakresie niskich częstości. Pojazdy Szynowe, Nr 3/1999.

[3] Elkins J., Wu H.: Angle of attack and distancebased criteria for climb derailment. Vehicle System Dynamics, Supplement 33 (1999),

[4] Gqsowski W., Sobczak M.: Układy biegowe wagonów kolejowych. Wydawnictwo Politechniki Poznańskiej, Poznań 1987.

[5] Knothe K.: Benchmark Test for Models of Railway Track and Vehicle/Track Interaction in the Low Frequency Range. Vehicle System Dynamics, Supplement 24 (1995). 
[6] Matej J.: Wplyw asymetrii struktury wózka na prędkość krytycznq wagonu towarowego $w$ ruchu po torze prostym. Zeszyty Instytutu Pojazdów,4(39)/2000,Politechnika Warszawska.

[7] Marciniak Z., Pawlak Z.: Uktad biegowy pojazdu szynowego jako obiekt diagnozowania dynamicznego. Pojazdy Szynowe, Nr 4/1999.

[8] Schliehen W.: Multibody System Dynamics Roots and Perspectives. Multibody System Dynamics No. 1, 1997.
[9] Schupp G., Weidemann Ch., Mauer L.: Modelling the Contact between Wheel and Rail within Multibody System Simulation. Vehicle System Dynamics, 2004, Vol.41, No. 5.

[10] Wallrapp O.: Review of Past Developments in Multibody System Dynamics at DLR - from FADYNA to SIMPACK. Vehicle System Dynamics, 2004, Vol.41, No. 5. 